\title{
Katılma Hesabı Kârının Dağıtımı ve Fıkhî Değerlendirmesi*
}

\author{
Cemal KALKAN**
}

\section{Öz}

Katılım bankalarının ana omurgasını oluşturan katılma hesapları, mudârabe sözleşmesi ile temellendirilmektedir. Bu hesaplarda mudârabe sözleşmesine dayanılarak toplanan fonlar, genellikle fon talebinde bulunanlara murâbaha yöntemiyle kullandırılmaktadır. Kullandırılan söz konusu fonlardan elde edilen gelirler de katılma hesabı havuzuna günlük olarak kaydedilmektedir. Elde edilen gelirlerden bankanın kâr payı, kendi hesabına günlük olarak aktarılırken hesap sahiplerinin kâr payları vadeleri geldiğinde hesaplarına aktarılmaktadır. Bu durum, katılma hesabından ayrılan rezervlerin yalnızca hesap sahiplerinin kâr payını etkilemesine sebep olmaktadır. Oysa kâr paylaşımının adil bir şekilde yapılması için rezervlerin/karşılıkların brüt kâr üzerinden yapılması gerekmektedir. Bunun için "Günlük Birim Değeri Hesaplama Tablosu”nun yeniden revize edilmesi zorunlu gözükmektedir. Aksi halde, bankanın günlük kâr payını kendi hesabına aktarması durumunda bilahare meydana gelebilecek bir zarar, bankanın kâr payını etkilemeyecektir. Bu da mudârabe akdinin gayesi olan kâr ortaklığına zarar verecektir. Bu çalışmada, hesap sahiplerinin kâr paylaşım oranlarını olumsuz etkileyen söz konusu durum, fıkhî açıdan tartışılacak ve sorunun çözümüne ilişkin bazı öneriler getirilecektir. Ayrıca günlük birim değer hesaplama tablosunda yer alan kalemlerin kapalı yönleri izah edilmeye çalışılacaktır.

Anahtar Kelimler: Mudârabe, Katılma Hesabı, Birim Değer, Kâr, Rezerv.

\section{Distribution of Participation Account Profit and Its Fiqhi Evaluation}

\author{
Absract \\ Participation account, which is the key element of participation banks, has been based \\ on mudaraba contract. In these accounts, the funds, acquired according to the mudaraba, are \\ given to whom appeals for funding with murabaha method. The revenues flowed from the \\ given funds are registered on daily basis to participation account pool. While dividend of the

\footnotetext{
* Araştırma Makalesi. Makale Gönderim Tarihi: 28.07.2020 Makale Kabul Tarihi: 31.12.2020

DOI: https://doi.org/10.52886/ilak.774907

** Dr. Arş. Gör., Selçuk Üniversitesi, İslami İlimler Fakültesi, İslam Hukuku Ana Bilim Dalı

Dr. Research Assistant, Selçuk University, Faculty of Islamic Sciences, Department of Islamic Law

kalkancemal@gmail.com ORCID: 0000-0002-0616-5303
} 
bank is transferred into its account on daily basis, dividends of the account holders are transferred when they fall due. In this case, the reserves that are taken out of the participation account, affect only profits of the account holders. However, for the fair distribution of profits, reserves/provisions must be made on gross profit. For this, it seems necessary to revise the "Daily Unit Value Calculation Table" again. Otherwise, if the bank transfers the daily dividend to its own account, any subsequent loss will not affect the bank's dividend. This will harm the profit partnership, which is the purpose of the mudaraba contract. In this work the abovementioned situation that affect negatively the rates of profit sharing of the account holders, will be discussed in regard of fiqh and some suggestions will be offered with intent to solve the problem. Besides, obscure sides of the elements that comprise the table of daily unit value calculation will be explained.

Keywords: Mudaraba, Unit value, Participation account, Profit, Reserve.

\section{Özet}

Katılım bankalarının ana omurgasını oluşturan katılma hesapları, mudârabe sözleşmesi ile temellendirilmektedir. Çağdaş literatürde mudârabe sözleşmesinin mâhiyetine yönelik iki temel yaklaşımdan söz edilmektedir. Birinci yaklaşıma göre mudârabe, klasik mudârabenin geliştirilmiş (المطوّرة) veya kayıtsız (المطلقة) versiyonudur. $\mathrm{Bu}$ yaklaşımda klasik mudârabenin temel yapısının aynen korunduğu varsayılmıştır. Buna göre faizsiz banka, sermayeyi çalıştırırken ve işletmecilere fon kullandırırken, akdin esas bir parçasıdır, yani akdin tarafıdır. İkinci yaklaşıma göre ise çağdaş mudârabe, klasik mudârabe formundan farklı olarak bünyesinde yeni bir taraf barındırır. Buna göre çağdaş mudârabe birbiriyle irtibatlı üç ilişkiden oluşur; sermaye sahipleri ile işletmeci mudâribler ve bu ikisi arasındaki ilişkiyi organize eden faizsiz banka. Günümüz faizsiz bankacılık uygulamalarında da ikinci yaklaşım benimsenmiştir. Mudârabe sözleşmesine dayandırılarak katılma hesapları için toplanan fonlar, genellikle fon talebinde bulunan müşterilere murâbaha yöntemiyle kullandırılmaktadır. Kullandırılan söz konusu fonlardan elde edilen gelirler de katılma hesabı havuzuna günlük olarak kaydedilmektedir. Elde edilen gelirlerden oluşan bankanın kâr payı, bankanın kendi hesabına günlük olarak aktarılırken hesap sahiplerinin kâr payları hesaplarına aynı gün aktarılmayıp vadeleri geldiğinde aktarılmaktadır. Bu durum, daha sonra katılma hesabından ayrılan rezervlerin yalnızca hesap sahiplerinin kâr payını etkilemesine sebep olmaktadır. Oysa kâr paylaşımının adil bir şekilde olması için rezervlerin/karşılıkların brüt kâr üzerinden yapılması gerekmektedir. Dolayısıyla katılma hesaplarının kârının hesaplandığı "Günlük Birim Değeri Hesaplama Tablosu"nun yeniden revize edilmesi zorunlu gözükmektedir.

Faizsiz bankaların müşterilerine taahhüt ettiği kâr payı oranlarını, ticaretin doğası ya da olağanüstü şartlar, olumlu ya da olumsuz olarak etkileyebilmektedir. Bunun için bankalar, dağıtıma uygun kârlara ulaşmak amacıyla katılma hesabı gelirinden bazı karşılıklar ayırmaktadır. Günlük Birim Değeri Hesaplama Tablosu'ndaki verilere göre bu karşılıklar, uygulamada yalnızca hesap sahiplerinin 
kâr payından karşılanmaktadır. AAOIFI [Accounting and Audinting Organization for İslamic Financial Institutions] İslamî Finans Kuruluşları İçin Muhasebe ve Denetleme Kurumu'nun (Hey'etü'l-muhâsebe ve'l-müraca'a li'l-müessesâti'lmâliyyeti'l-İslâmiyye) yayımlandığı faizsiz bankacılık standartlarına (el-Meâyîru'şşer'ıyye) göre de bu karşlıkların katılma hesabının gayrisafi kârından alınması gerekmektedir. Kanaatimizce bu karşılıkların, mudârabe gideri olarak kabul edilmesi, mudârabe akdinin muktezasına daha uygundur. Çünkü mudârabe sözleşmesinde giderin, önce toplam kârdan karşılanması gerekmektedir. Zaten katılım bankaları muhasebe tablolarında söz konusu karşılıklar "gider" kalemi olarak kaydedilmektedir. Dolayısıyla söz konusu karşılıkların gayri safi kârdan karşılanması zorunlu olmaktadır. Bu durumda özel ve genel karşılıklar, sadece hesap sahiplerine dağıtılacak kârı değil de aynı zamanda bankanın payını da etkileyecektir. Katılım bankasını da aynı şekilde etkileyeceği için banka karşıılık ayırırken daha dikkatli davranmaya özen gösterecektir. Böylece hesap sahipleri ile banka kâr paylaşım oranlarına uygun olarak kârlarını almış olacaklardır. Aksi halde, bankanın günlük kâr payını kendi hesabına aktarması durumunda bilahare meydana gelebilecek bir zarar, bankanın kâr payını etkilemeyecektir. Bu da fikıh kaynaklarında ele alınan mudârabe akdinin gayesi olan kâr ortaklığına zarar verecektir.

Kâr hesaplama tablosundaki "Katılma Hesaplarına Dağıtılacak Kârdan Ayrılan Tutarlar" başlıklı kalem, çağdaş literatürde kâr dengeleme rezervi olarak ifade edilmektedir. Söz konusu rezerv, uygulamada yalnızca hesap sahiplerinin kârından ayrılmaktadır. Hâlbuki hesap sahipleri ile bankanın birlikte yararlandığı bu rezervin, yalnızca hesap sahibinin gelirinden karşılanması, kârda ortaklık anlayışına zarar vermektedir. Kanaatimizce bu rezervin brüt kârdan karşılanması daha isabetli bir karar olacaktır. Ayrıca kâr dengeleme rezervi sebebiyle banka, diğer faizli bankaların faiz ödemeleri gibi sabit oranlı kâr dağıtımı yapabilmektedir. $\mathrm{Bu}$ da katılım bankalarının faizli bankalarla olan benzerliklerini daha da artırarak kamuoyunda olumsuz algının oluşmasına yol açabilmektedir.

İslamî Finans Kuruluşları İçin Muhasebe ve Denetleme Kurumu'nun (AAOIFI) standartlarında ayrıntılı olarak incelenen yatırım riskleri rezervi, katılım bankalarının kâr hesaplama tablosunda yer almamaktadır. Ancak sektör temsilcileri, bu rezervin kâr dengeleme rezervinin içinde olduğunu söylemektedir. $\mathrm{Bu}$ rezervin fikha uygun olabilmesi için müstakil olarak ve yalnızca hesap sahiplerinin kârından ayrılması gerekmektedir.

Konunun bir başka yönü katılma hesaplarının masrafları ile ilgilidir. Faizsiz bankaların ana omurgasını oluşturan katılma hesaplarının bazı masraflarından bahsedilmektedir. Söz konusu masraflar, doğrudan ve dolaylı olmak üzere ikiye ayrılmaktadır. Faizsiz Banka, doğrudan yaptığı masrafları mudârabe sermayesinden, dolaylı yaptığı masrafları ise kendi özkaynağından karşılamaktadır. Çünkü banka dolaylı yaptığı harcamalar karşılığında katılma hesabına ait kârdan pay almaktadır. Ancak mudârabe yatırımına yönelik doğrudan 
yapılan masraflar hususunda ise dünya genelinde faaliyet gösteren faizsiz bankalar arasında henüz bir birlik oluşmamıştır. 1980'lerden beri ülkemizde faizsiz bankacılık hizmeti veren kurumların kârlarının hesaplandığ 1 "Günlük Birim Değeri Hesaplama Tablosu" içerisinde katılma hesabı masraflarına dair herhangi bir kalem bulunmamaktadır. Katılım bankalarının ana omurgasını oluşturan katılma hesaplarının gider kaleminin söz konusu tabloda yer almaması, kanaatimizce faizsiz bankacılık anlayışına zarar vermektedir. Günümüz bazı İslam İktisadı araştırmacıları katılma hesabı masraflarının kâr hesaplama tablolarında yer almaması sorununa çözüm olarak katılma hesabı için ayrı bir departman kurulmasını teklif etmiştir. Böylece yeni kurulan bu departman sayesinde katılma hesabı masraflarının daha kolay bir şekilde hesaplanacağı öngörülmüştür. Bu çalışmada, hesap sahiplerinin kâr paylaşım oranlarını olumsuz etkileyen söz konusu durum, fıkhî açıdan tartışılacak ve sorunun çözümüne ilişkin bazı öneriler getirilecektir. Ayrıca günlük birim değer hesaplama tablosunda yer alan kalemlerin kapalı yönleri izah edilmeye çalışılacaktır.

\section{Summary}

Participation account, which is the key element of participation banks, has been based on mudaraba contract. There are two basic approaches to the nature of mudaraba contract in contemporary literature. According to the first approach, mudaraba is the enhanced (المطوّرة) version of the classical mudaraba. For this reason, it is assumed that the basic structure of classical mudaraba is preserved. Accordingly, the interest-free bank is an essential part of the contract, that is, the party to the contract, while operating the capital and making the operators use funds. According to the second approach, contemporary mudaraba, unlike the classical mudaraba application, contains a new side. According to this, contemporary mudaraba consists of three interrelated relations; capital owners and operator mudaribs and the interest-free bank that organizes the relationship between these two. In practice, the second approach has been adopted. The funds, acquired according to the mudaraba, are given to whom appeals for funding with murabaha method. The revenues flowed from the given funds are registered on daily basis to participation account pool. While dividend of the bank is transferred into its account on daily basis, dividends of the account holders are transferred when they fall due. In this case, the reserves that are taken out of the participation account, affect only profits of the account holders. However, for the fair distribution of profits, reserves/provisions must be made on gross profit. For this, it seems necessary to revise the "Daily Unit Value Calculation Table" again.

The nature of the trade or extraordinary conditions may positively or negatively affect the profit share rates committed by interest-free banks to their customers. For this, banks set aside some provisions from participation account income in order to reach profits suitable for distribution. According to the data in 
the Daily Unit Value Calculation Table, these provisions are only covered by the profit share of the account holders in practice. According to the interest-free banking standards (al-Ma'âyir al-Shar'iyyah) published by the institution AAOIFI (Accounting and Audinting Organization for İslamic Financial Institutions/Hay'a al-Muhasabah wa al-Muraja'a li al-Muassasât al-Mâliyyah al-İslâmiyyah) these provisions must be taken from the gross profit of the participation account. As for us, accepting these provisions as mudaraba expenses is more appropriate for the mudaraba contract. Because in the mudaraba contract, the expenses must first be covered from the total profit. In fact, these provisions are recorded as an "expense" item in the accounting statements of participation banks. Therefore, it is obligatory to meet these provisions from gross profit. In this case, specific and general provisions will affect not only the profit to be distributed to the account holders, but also the bank's share. Since it will affect the participation bank in the same way, the bank will pay attention to be more careful while allocating provisions. Thus, the account holders and the bank will receive their profits in accordance with the profit sharing ratios. Otherwise, if the bank transfers the daily dividend to its own account, any subsequent loss will not affect the bank's dividend. This will harm the profit partnership, which is the aim of the mudaraba contract, which is discussed in the sources of fiqh.

The item titled "Amounts Set aside from Profit to be Distributed to Participation Accounts" in the profit calculation table is referred to as the profit balancing reserve in the contemporary literature. The reserve in question is separated from the profit of the account holders in practice. However, the fact that this reserve, which is used by the account holders and the bank together, is met only from the income of the account holder, harms the understanding of partnership in profit. As for us, it would be a more appropriate decision to meet this reserve from gross profit. In addition, due to its profit balancing reserve, the bank can distribute profits at a fixed rate, just like the interest payments of other interest-bearing banks. This, in turn, further increases the similarities of participation banks with interest-bearing banks, and may lead to a negative perception in public opinion.

The investment risks reserve, which is examined in detail in the standards of AAOIFI (Accounting and Audinting Organization for İslamic Financial Institutions) is not included in the profit calculation table of participation banks. However, sector representatives say that this reserve is within the profit balancing reserve. In order for this reserve to be in compliance with fiqh, it must be separated from the profits of the account holders individually and only.

Another aspect of the issue is related to the costs of participation accounts. Some costs of participation accounts, which form the backbone of interest-free banks, are mentioned. These costs are divided into two as direct and indirect. The Interest Free Bank covers its direct expenses from the mudaraba capital, and its indirect expenses from its own equity. Because the bank receives a share of the 
profit of the participation account in return for its indirect expenditures. However, regarding the direct costs of mudaraba investment, a union has not yet been formed among the interest-free banks operating around the world. There is no item related to participation account expenses in the "Daily Unit Value Calculation Table", in which the profits of institutions providing interest-free banking services in our country since the 1980s are calculated. As for us, the fact that the expense item of participation accounts, which constitute the main backbone of participation banks, is not included in the table in question, damages the understanding of interest-free banking. As a solution to the problem that today's Islamic Economics researchers do not include the participation account expenses in the profit calculation tables; proposed the establishment of a separate department for the participation account. Thus, thanks to this newly established department, it is foreseen that the costs of participation account will be calculated more easily.

In this work the abovementioned situation that affect negatively the rates of profit sharing of the account holders, will be discussed in regard of fiqh and some suggestions will be offered with intent to solve the problem. Besides, obscure sides of the elements that comprise table of daily unit value calculation will be explained.

\section{Giriş}

Katılım bankaları, mudârabe sözleşmesine dayanarak katılma hesaplarına fon toplamaktadır. Daha sonra bu fonları, finansman talebinde bulunanlara çeşitli yöntemlerle kullandırmaktadırlar. Katılım bankaları da çoğunlukla murâbaha yöntemini tercih etmektedir.

Katılma hesaplarında toplanan fonların birbirleriyle karıştırılması gerektiğinden bankalar, yayımlamış olduğu sözleşme metinlerinde bunu açıkça zikrederler. ${ }^{1}$ Ayrıca sermaye sahiplerinin katılma hesabı açması, bankanın yeni sermaye kabul etmesine örtülü bir şekilde izin vermeleri anlamına gelmektedir. ${ }^{2}$ Böylece hesap sahipleri, sermayelerinin karıştırılmasına dolaylı olarak izin vermiş sayılırlar.

Katılma hesabı sermayeleri birbirleriyle hükmen karışmış ve çalıştırılmış kabul edildiğinden, hesap sahiplerinin sermayeleri âtıl kalmamaktadır. ${ }^{3}$ Bu sebeple katılma hesabında bulunan sermayelerin hangisinin çalıştırıldığının pek önemi yoktur. Çünkü muayyen bir sermaye ile iş yapılmayıp sermayenin tamamı üzerinden iş kabul edilmekte böylece kâr ve zarar sermayenin tamamına yayılmaktadır. Ayrıca tahakkuk eden kârın hemen taksim edilmemesi, sermayenin

\footnotetext{
${ }^{1}$ Muhammed Tâkî el-Osmânî, Buhûsun fî kadâya fikhiyye muâsıra (Daru'l-kalem, 2011), 2/87.

2 el-Allâme Muhammed Veli b. Resûl el-İzmîrî, Kemâlü'd-dirâye fî cemîi'r-rivâye min şürûhi'l-Mültekâ (Beyrut: Dâru'l-kütübi'l-ilmiyye, 2017), 8/332.

${ }^{3}$ Kevser Abdulfettah Mahmut el-Ebecî, "Kıyâsu ve tevzîu'r-ribh fi'l-benki'l-İslâmî", Mevsûä̈'l-İktisâdi'lİslâmî (Kahire: Dâru's-selâm, 2009), 134.
} 
belli bir vadesinin olduğunu göstermektedir. Söz konusu vade içerisinde diğer sermayelerin yatırım sürecine sokulması mümkün olmaktadır. Dolayısıyla sermayeler birbirlerinin fayda ve zararından etkilenmektedir. Zaten ortaklık da bu etkiyi gerektirmektedir. ${ }^{4}$

Bazen bankalar, kendi özvarlıklarına öncelik vererek katılma hesabı sermayesi kısmen âtıl bırakabilmektedir. Uygulamada faizsiz bankaların hangi sermayelere öncelik vereceği belli değildir. Bazı bankalar kendi özvarlıklarının yatırımına kimileri de katılma hesaplarına öncelik vermektedir. AAOIFI şerî standartlarına göre, banka farklı bir uygulama yaparak sermayeleri âtıl bırakacaksa bunu önceden açıklaması gerekmektedir. ${ }^{5}$ Aksi halde hesap sahipleri, sermayelerinin âtıl kalmasıyla mağdur olabilmektedir.

Ülkemizde katılma hesabının işleyişi genelde şöyle gerçekleşmektedir: Müşteri katılım bankasına başvurur ve mudârabe temelli bir katılma hesabı açtırır. Daha sonra bu hesaba para yatıırı ardından bu paradan zorunlu karşılık ve ankes payı düşülür. Katılım bankası da geriye kalan parayı fon olarak kullandırır. ${ }^{6}$ Katılma hesabı fonları, çoğunlukla murâbaha yöntemiyle kullandırıldığı için günlük sabit taksitler şeklinde havuza gelir kaydedilmektedir. Bu gelirler, birim değer hesaplama yöntemiyle hesaplanarak hesap sahiplerine dağıtılmaktadır. Birim değer hesaplama tablosunu oluşturan kalemler, ilgili yönetmeliğin ekinde ayrıntılı olarak açıklanmıştır.

\section{Günlük Birim Değer Hesaplama Tablosunda Yer Alan Kalemler}

Günlük birim değer hesaplama tablosu, "Mevduat ve Katılım Fonunun Kabulüne, Çekilmesine ve Zamanaşımına Uğrayan Mevduat, Katılım Fonu, Emanet ve Alacaklara İlişkin Usul ve Esaslar Hakkında Yönetmeliğge" göre belirlenmiştir.7

Söz konusu tabloda 23 kalem bulunmaktadır. "Hesap Sahibinin Kâra Katılma Oranı" ile hesapta toplanan fonların çalıştırılması neticesinde oluşacak kârdan hesap sahiplerinin alacağı kâr payı miktarı kast edilmektedir. Hesap sahipleri ile banka arasındaki kâr paylaşım oranları, katılma hesabındaki sermayenin vadesi ve miktarına göre değişebilmektedir. Ülkemizdeki uygulamada kâr paylaşım oranları, hesap sahipleri için toplam kârın \% 80-90'1, banka için ise \% 20-10'u şeklinde

\footnotetext{
${ }^{4}$ Latif Muhammed Abdullah Serhî, Müşkilâtü ihtisâbi'l-erbâh ve tevzîihâ fi'l-bunûki'l-İslâmiyye (Camiatü'lYermûk, 1995), 102.

${ }^{5}$ Heyet, el-Meâyîru'ş-şer'ıyye: en-nassu'l-kâmil li'l-mâyîri'ş-şeri'yye (AAOIFI) (Menâme: Daru'l-meymân, 2015), 1011.

${ }^{6}$ Albarakatürk Katılım Bankacılığı Sistemi Çalışma Esasları ve Uygulaması (b.y.: Albaraka Yayınları, ts.), 16. https://docplayer.biz.tr/68013546-Katilim-bankaciligi-sistemi-calisma-esaslari-ve-uygulamasi.html

7 BDDK Bankacılık Düzenleme ve Denetleme Kurumu, "Mevduat ve Katılım Fonunun Kabulüne, Çekilmesine ve Zamanaşımına Uğrayan Mevduat, Katılım Fonu, Emanet ve Alacaklara Illişkin Usul ve Esaslar Hakkında Yönetmelik", Resmi Gazete (25 Mart 2020).

https://www.mevzuat.gov.tr/Metin.Aspx?MevzuatKod=7.5.10735\&Mevzuatlliski=0\&sourceXmlSearch= mevduat\%20ve\%20kat\%C4\%B11\%C4\%B1m.
} 
olabilmektedir. ${ }^{8}$ Katılma hesabına sermaye yatıran hesap sahiplerinin kâr paylaşım oranları aynı olabildiği gibi farklı da olabilmektedir. ${ }^{9}$ Her bir hesap sahibinin kâr paylaşım oranı farklı olduğunda banka, katılma hesabının ortalama kâr paylaşım oranını tespit etmekte ve kendi payına ve hesap sahiplerinin tamamına düşen kâr payı oranı belirlemektedir.

Tablodaki "Hesap Sahibinin Zarara Katılma Oranı" ifadesiyle de mevzubahis hesaplarda toplanan fonların işletilmesi neticesinde oluşacak zarar ve giderlerden hesap sahiplerine düşen pay oranı kast edilir. Ayrıca ilgili yönetmeliğin dördüncü maddesinin (4) numaralı fikrasının (g) bendine göre hesap sahibinin zarara katılma oranı $\% 100^{\prime}$ dür. ${ }^{10}$

Günlük birim değer hesaplama tablosunu oluşturan kalemleri sırasıyla şöyle izah edebiliriz:

\begin{tabular}{|c|c|c|c|c|c|c|c|}
\hline \multicolumn{8}{|c|}{ Günlük Birim Değeri Hesaplama Tablosu } \\
\hline & \multirow{2}{*}{\begin{tabular}{|l|} 
Para Cinsi \\
Hesap Sahibinin Kara Katılma Oranı
\end{tabular}} & \multicolumn{3}{|c|}{ T L } & \multirow[t]{2}{*}{ Toplam } & \multirow{2}{*}{ 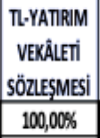 } & Genel Toplam \\
\hline & & $75,00 \%$ & $80,00 \%$ & $90,00 \%$ & & & \\
\hline & Hesap Sahibinin Zarara KatıIma Oranı & $87,50 \%$ & $90,00 \%$ & $95,00 \%$ & & $100,00 \%$ & \\
\hline 1 & Katilma Hesaplan Toplam Tutan & $177.025,00$ & 718780,00 & $114.201,00$ & $1.010 .006,00$ & $126.000,00$ & $1.136 .006,00$ \\
\hline 2 & Kar/Zarardan Pay Almayan Katilma Hesaplan Tutarı & $2.934,00$ & 2,00 & $7.070,00$ & $10.006,00$ & $1.000,00$ & $11,006,00$ \\
\hline 3 & Kar/Zarardan Pay Alan Katilma Hesaplan Tutar (1-2) & $174.091,00$ & 7187778,00 & $107.131,00$ & $1.000 .000,00$ & $125.000,00$ & $1.125 .000,00$ \\
\hline 4 & Hesap Degerleri & $1.707,31$ & $3.234,93$ & 511,76 & & $1.250,00$ & \\
\hline 5 & Birim Deg̉eri & 102,38690 & 223,60540 & 210,57594 & & 101,25000 & \\
\hline 6 & Birim Hesap Değeri $\left(4^{*} 5\right)$ & $174.806,61$ & $723.346,84$ & $107.763,76$ & $1.005 .917,22$ & $126.562,50$ & $1.132 .479,72$ \\
\hline
\end{tabular}

1- Bu tutar, katılma hesaplarına yatırılan fonları ifade eder.

2- Bu tutarla, katılma hesaplarına yatırılan fonlardan valör uygulaması nedeniyle kâr dağıtımı süresi henüz başlamadığı için hesaplamaya dâhil edilmeyen fonlar kast edilir.

3- Toplam tutardan pay almayan katılma hesabı miktarının çıarılması neticesinde oluşan tutarı ifade eder.

4- Katılma hesaplarına para yatıran hesap sahiplerinin fondaki mevcut aktiflere katılım payını gösteren bir katsayıdır.

5- Katılma hesaplarında kâr-zarar gelişimini gösteren, kâr edildiğinde artan, zarar edildiğinde azalan bir katsayıdır. Bu katsayı, bankanın faaliyete geçtiği gün 100 olarak kabul edilmektedir.

\footnotetext{
8 TKBB Türkiye Katılım Bankaları Biriliği, "Hesap Sahiplerine Dağıtılan Kar Payı Oranları", Organizasyon, (31 Mart 2020), https://www.tkbb.org.tr/kar-paylari.

9 AAOIFI, el-Meâyîru'ş-şer'iyye, (Riyad: Dâru'l-Meymân, 2015), 1016.

10 TCMB Türkiye Cumhuriyeti Merkez Bankası, “Mevduat ve Kredi Faiz Oranları ve Katılma Hesapları Kâr ve Zarara Katılma Oranları Hakkında Tebliği”, Resmi Gazete (31 Mart 2020) https://www.resmigazete.gov.tr/eskiler/2020/02/20200210-9.htm.
} 
6- Katılma hesabının mevcut değerini açıklayan ve birim değeri ile hesap değerinin çarpılmasıyla hesaplanan, katılma hesabı sahibinin hakkını ifade eden bir tutardır.

Kâr hesaplama tablosundan ayrılan karşılıklar şöyle sıralanmıştır:

\begin{tabular}{|c|c|c|c|c|}
\hline 7 & Genel Karşillkkar & $12.745,00$ & $1.424,00$ & $14.169,00$ \\
\hline 8 & Katlma Hesaplanna Dağtillacak Kâtrlardan Aynlan Rezervler & $8.255,00$ & 923,00 & $9.178,00$ \\
\hline 9 & Zorunlu Karşalkklar (6* Zorunlu Karş̣lik Oranı) & $55.325,45$ & $6.183,00$ & $61.508,45$ \\
\hline 10 & Katilma Hesaplan Ankes Payı & $84.661,00$ & $9.406,78$ & $84.661,00$ \\
\hline 11 & Kullandinlabilir Fon $(6+7+8) \cdot(9+10)$ & $886.930,77$ & $113,319,72$ & $1.009 .657,27$ \\
\hline 12 & Plasmanlar & $880.590,00$ & $112,000,00$ & $992,590,00$ \\
\hline 13 & Atl Fon (11-12) & $6.340,77$ & $1.319,72$ & \\
\hline 14 & Kullandinlan Fon Fazlası (12-11) & 0,00 & 0,00 & \\
\hline
\end{tabular}

7- "Katılma hesabı kaynaklı kredilerden Kredilerin Sinıflandırılması ve Bunlar İçin Ayrılacak Karşılıklara İliş̧kin Usul ve Esaslar Hakkında Yönetmeliğge ${ }^{11}$ göre Standart Nitelikli Krediler ile Yakın İzlemedeki Krediler arasında izlenenler için ayrılan genel karşılıkların katılma hesaplarına yansıtılan kısmıdır." Yönetmeliğin onuncu maddesinde genel karşılıklar, on birinci maddesinde ise özel karşllılar belirlenmiştir.

8- İlgili yönetmeliğin 6. maddesinin (8) numaralı fıkrası çerçevesinde, ayrılan rezervleri ifade eder.

9- Bankaların bloke ederek Merkez Bankasında tuttuğu miktardır. Bu miktar, Birim Hesap Değeri ile belirlenen oranın çarpılmasıyla bulunur.

10- Katılım bankalarının, kendi kasasında yahut muhabir bankalarda Ankes (nakit para) adı altında tutmak zorunda olduğu miktarlardır.

11- İlgili karşılıklar çıkarıldıktan sonra bankanın kullandırabileceği fonu ifade eder.

12- Kullandırılan bütün fonlar kast edilmektedir.

13- Kullandırılabilir fon miktarından kullandırılan fon miktarının düşülmesi neticesinde bulunan miktardır.

14- Kullandırılan fon miktarından, kullandırılabilir fon miktarının çıkarılması neticesinde oluşan miktardır. Bu miktar, bankanın kullandırılabilir fon miktarından daha fazla fon kullandırması durumunda gerçekleşir.

11 https://www.resmigazete.gov.tr/eskiler/2016/06/20160622-3.htm, md. 3/d. 
Katılma hesabı gelir ve giderleri şöyle belirlenmiştir:

\begin{tabular}{|c|c|c|c|c|c|c|c|c|}
\hline 15 & & Katilma Hesabı Gelirleri (a+b+c+d+e) & 44,44 & 194,79 & 32,29 & 271,52 & 43,50 & 315,02 \\
\hline & a & Kar Payı Gelirlerinin Katilım Payı & 36,32 & 160,32 & 26,87 & 223,52 & 40,00 & 263,52 \\
\hline & a.1 & Katlma Hesabı KaynakI Kullandinlan Kredilerden Elde Edilien Kar Payı Gelinten & & & & 278,69 & 40,00 & 318,69 \\
\hline & a.2 & Kullandirnlan Fon Fazlasina Isabet Eden Kor & & & & 0,00 & & 0,00 \\
\hline & $b$ & Terkin Edilen Kredilerden Yapilan Tahsilatlar & 1,69 & 7,18 & 1,13 & 10,00 & 0,00 & 10,00 \\
\hline & c & Özel Karşilkkların Iptalleri & 2,54 & 10,77 & 1,69 & 15,00 & 1,00 & 16,00 \\
\hline & d & Genel Karşılıklarin Iptalleri & 0,85 & 3,59 & 0,56 & 5,00 & 0,50 & 5,50 \\
\hline & e & Katılıa Hesaplarina Dağitllacak Kârlardan Ayrilan Karşıllik Iptalleri & 3,04 & 12,92 & 2,03 & 18,00 & 2,00 & 20,00 \\
\hline 16 & & Katılma Hesabı Giderleri (a+b+ctd+e) & 8,12 & 34,46 & 5,42 & 48,00 & 3,75 & 51,75 \\
\hline & a & Katulma Hesabı Kaynaklı Kullandinlan Menkul Deǧerlere lisiskin Giderler & 0,00 & 0,00 & 0,00 & 0,00 & 0,00 & 0,00 \\
\hline & b & Özel Karşshk Giderleri & 1,69 & 7,18 & 1,13 & 10,00 & 2,00 & 12,00 \\
\hline the & c & Genel Karşllik Giderleri & 1,01 & 4,31 & 0,68 & 6,00 & 0,75 & 6,75 \\
\hline & d & TMSF Prim Giderleri & 0,34 & 1,44 & 0,23 & 2,00 & 0,00 & 2,00 \\
\hline 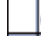 & e & İhtiyati Karşılık Giderleri & 5,07 & 21,54 & 3,39 & 30,00 & 1,00 & 31,00 \\
\hline
\end{tabular}

Katılım bankalarının en önemli gelir kalemini katılma hesapları oluşturmaktadır. Kullandırılan fon gelirleri dışında bazı gelirler de vardır. Bunlar terkin edilen katılma hesabı kaynaklı fonlardan yapılan tahsilâtlar ile iptal edilen genel, özel ve ihtiyati karşılıklardır. Katılma hesabı giderleri daha ziyade TMSF primleri ve karşılık giderlerinden oluşmaktadır.

Katılma hesaplarının gelir ve giderleri hesaplandıktan sonra, ikisi arasındaki fark dağıtılacak kâr ve zararı ortaya koyacaktır. Bazen katılım bankaları, kendi haklarından feragat ederek hesap sahipleri lehine ilave kâr payı verebilmektedir. Katılma hesabı karının hesaplanması için şu işlemler yapılmaktadır.

\begin{tabular}{|c|c|c|c|c|c|c|c|}
\hline 17 & Sermayeden Transferler & 0,00 & 0,00 & 0,00 & 0,00 & 0,00 & 0,00 \\
\hline 18 & Dağıtılacak Kar/Zarar (15-16) & 36,32 & 160,32 & 26,87 & 223,52 & 39,75 & 263,27 \\
\hline 19 & Katılma Hesaplarına Dağııllacak Kârlardan Ayrllan Tutarlar & 1,82 & 8,02 & 1,34 & 11,18 & 1,99 & 13,16 \\
\hline 20 & Dağttlan Kar/Zarar (17-18) & 34,51 & 152,31 & 25,53 & 212,34 & 37,76 & 250,10 \\
\hline 21 & Yeni Birim Hesap Değeri $(6+19)$ & $174.841,11$ & $723.499,15$ & $107.789,29$ & $1.006 .129,56$ & $126.600,26$ & $1.132 .729,82$ \\
\hline 22 & Yeni Birim Değeri $(20: 4)$ & 102,407111 & 223,652482 & 210,625821 & & 101,280210 & \\
\hline 23 & Vadesi Gelmeyen Hesapların Kar Payları (Gider Reeskontları) (20 - 3) & 750,11 & $4.721,15$ & 658,29 & $6.129,56$ & $1.600,26$ & $11.509,00$ \\
\hline
\end{tabular}

Dağıtılacak kâr ve zarar hesaplanırken "Birim-Hesap Değer Yöntemi" kullanılır. Mevzubahis yöntem; "Birim Değer, Hesap Değer ve Birim-Hesap Değeri" olmak üzere üç kavramdan oluşmaktadır. Bunun formülü şu şekildedir:

$\mathrm{BD}=$

BD*HD Toplamı + Günlük Kâr - Zarar Karşılı̆̆g

\section{Hesap Değerleri Toplamı}

A, B ve C şahısları, "birim değeri" 100 olan katılma hesabına sirasıyla $1000 \mathrm{tl}$, $4950 \mathrm{tl}$ ve $4050 \mathrm{tl}$ yatırır. Hesap sahiplerinin "hesap değeri”, yatırılan meblağların "birim değere" bölünmesiyle bulunur. Buna göre her bir hesap sahibinin hesap değerleri sırasıyla $10 \mathrm{tl}, 49.5 \mathrm{tl}$ ve $40.5 \mathrm{tl}$ 'dir. Birim hesap değerleri ise ilk gün için yatırılan tutarlarla aynıdır. Çünkü henüz bu tutarlar banka tarafından işletilmemiştir. Hesap sahiplerinin fonu işletilerek 6250 tl kâr ettiğini farz edelim. 
Banka ile hesap sahipleri arasındaki kâr paylaşım oranı \%20'ye \%80 olduğu için banka 1250 tl kâr alma hakkı elde eder. Kalan 5000 tl kâr ise hesap sahiplerine dağıtılır. Artık fonun toplam değeri 15.000 tl'dir. Bu tutarın fonun bir önceki günkü toplam hesap değerine -ki henüz 100'dür- bölünmesiyle yeni birim değere ulaşllır. Bu durumda birim değer 150'ye dönüşür. Birim değer ile her bir hesap sahibinin "hesap değeri" çarpılırsa hesap sahiplerinin hak iddia edebileceği tutar olan "birim hesap değere" ulaşılır. O zaman A, (10x150) 1500 tl, B, (49.5x150) 7425 tl ve C de $(40,5 \times 150) 6075$ tl alacaktır.

Bu aşamada D fona 3000 tl ile katılır. Birim değer 150 olduğu için D'nin yatırdığ 13000 も'nin hesap değeri $20^{\prime}$ dir. Bu durumda toplam hesap değeri 150 'den 170 'ye çıkmış olur. Fonun toplam değeri ise artık 18.000 も’ye ulaşmıştır. Bu fonun işletilmesinden 3000 も kâr elde edilir ve banka \%20'lik kâr payını (600 も) aldığında fona dağıtılacak 2400 も kâr kalır. Fonun büyüklüğü bu kârla birlikte 20.400 も’ye ulaşmıştır. Bu rakam bir önceki günün toplam hesap değerine bölünecek olursa birim değer olarak 170 rakamına ulaşılır. Birim değer ile hesap değerleri çarpılarak da her bir hesap sahibinin mevcuttaki hakkına ulaşılır. O zaman A, (10x170) 1700 , B, (49.5x170) 8415 も, C, (40.5x170) 6885 も ve D de (20x170) 3400 も alacaktır. ${ }^{12}$

Tarafların günlük olarak kâr paylarını almaları klasik fıkıh literatürü üzerinden şöyle temellendirmek mümkündür. Örneğin Hanbelî fikıh kaynaklarında günlük kâr dağıtımından bahsedilmektedir. Mudârabe tarafları kârın tamamını veya bir kısmını paylaşmak üzere veya her gün kârdan belli bir miktar almak üzere anlaşsa sonra da kârı aralarında paylaştırsalar veya mudârabe devam ederken taraflardan biri diğerinin izniyle kârdan hissesini alsa daha sonra da mudârabede zarar meydana gelse; mudârib, almış olduğu kârı iade eder. ${ }^{13} \mathrm{Bu}$ ifadeler kârın günlük olarak alınabileceğine işaret etmektedir.

Sonuç olarak birim hesap-değer yönteminin kâr hesaplamada gayet başarılı olduğu söylenebilir. Ancak bu yöntem ile kâr hesaplanırken bazı rezervler ayrılmakta ve bunların da hatalı bir şekilde ayrılması bu yöntemin başarısına gölge düşürmektedir. Kâr dengeleme ile yatırım riskleri rezervleri, özel-genel karşılıklar zamanında ve ilgili kâr payından ayrıldığında, söz konusu hatalar ortadan kalkmış olacaktır.

\footnotetext{
12 Ishak Emin Aktepe, Katılım Finans (İstanbul: TKBB Yayınları, 2017), 161.

${ }^{13}$ Fütûhî İbnü'n-Neccâr, Müntehe'l-irâdât fì cem'i'l-Mukni' ma'a't-Tenkîh ve ziyâdât, thk. Abdulmuhsin etTürkî (Beyrut: Müessesetü'r-risâle, 1999), 3/34; Merî b. Yusuf Makdisî (Kermî), Gayetü'l-müntehâ fì cem' '̂́liknâ ve'l-müntehâ, nşr. Yasin İbrahim Mezrûî, Raid Yusuf Rûmî (Kuveyt, 2007), 1/696. Ayrıntlı bilgi için bkz. Cemal Kalkan, Mudârabe Sözleşmesinde Kâr (İstanbul: İstanbul Üniversitesi Sosyal Bilimler Enstirtüsü, Doktora Tezi, 2020), 176.
} 


\section{Günlük Birim Değer Hesaplama Tablosunun Fıkhî Değerlendirmesi}

\section{A. Sermayeden Ayrilan Rezervler}

Katılma hesabına yatırılan mudârabe sermayesi işletim sürecine sokulmadan birtakım kesintilere maruz kalmaktadır. Bunlar, katılım bankalarının Merkez Bankası için mecburen ayırdığı; zorunlu (munzam) karşılıklar ve bu bankaların kendi iç yönetmelikleri gereği ayırdığı ankes paylarıdır.

Zorunlu karşılıklar, kamu otoritesinin katılma hesaplarının vadelerine göre bankalardan ayırmalarını istediği meblağlardır. ${ }^{14}$

Katılım fonunun vadesine göre talep edilen zorunlu karşılık oranları farklılık arz etmektedir. Merkez Bankası, iki haftada bir Cuma günü zorunlu karşılıklara tabi olan katılım bankalarının ne kadar zorunlu karşılık ayırması gerektiğini açıklar. Daha sonra bu açıklama kapsamında hesaplanan tutarın Merkez Bankası nezdinde yükümlü kurumlar tarafından ayrılmasını talep eder. Yani zorunlu karşılıkların tesis müddeti 14 gün kabul edilir.

Katılma hesaplarının ankes payı ise bankanın kendi kasasında yahut muhabir bankalarda nakit para olarak tutmak zorunda olduğu miktardır. ${ }^{15}$ Ankes payı ilgili yönetmeliğin ek'inde ayrıntılı olarak izah edilmiştir:

Mevzubahis rezervler, kamu otoritesinin mecbur tutması yahut ilgili sektörün şartları gereği uygulanmaktadır. ${ }^{16} \mathrm{Bu}$ rezervlerin, sermaye sahiplerinin lehine olduğu ifade edilmekte ve bununla da şerîatın korunmasını zorunlu gördüğü beş unsur (zarurât-ı hamse) kapsamındaki "mal"ın güvenceye alındığı vurgulanmaktadır. ${ }^{17}$

Kamu otoritesinin zorunlu tutmuş olduğu bu karşılıkların nemalarının kullanılıp kullanılmayacağı çağdaş literatürde tartışılmaktadır. Merkez bankasından alınan nemanın, enflasyon oranına kadarı fıkhî açıdan bir sorun teşkil etmediği, enflasyon oranını aşan kısmının ise Tasarruf Mevduat Sigorta Fonu (TMSF) prim ödenmesi için kullanılabileceği söylenmiştir. Ayrıca katılım bankalarının zorunlu karşılıkları faiz geliri elde etmek için Merkez Bankasına

\footnotetext{
14 Ebecî, “Kiyâsu ve tevzîu'r-ribh”, 133,145; Muhammed Abdulgaffar Şerif, "Ahkâmu tekvîni'1muhassasât fi'l-müessesâti'l-mâliyyeti'l-İslâmiyye", el-Mu'temeru'l-fikhî er-râbi' li'l-müessesâti'l-mâliyeti'lİslâmiyye (Kuveyt: Kervan Plaza, 2011), 20; “Zorunlu Karşılıklar Hakkında Tebliğ", Resmi Gazete (25 Aralık 2013).

15 Ebecî, "Kıyâsu ve tevzîu'r-ribh", 45; Servet Bayındır, "Faizsiz Bankacılıkta Kâr-Zarar Dağıtımı Uygulamasının Fıkhî Durumu", Faizsiz Finans ve Tasarruf sistemleri ile Illgili Güncel Uygulamalar (Ankara: Diyanet İşleri Başkanlığı Yayınları, 2019), ss. 100-115, 279.

${ }^{16}$ Ebecî, "Kiyâsu ve tevzîu'r-ribh", 145; Musa Adem İsa, "el-Vedâiu'l-masrifiyye ve kavâidü tevzîi'r-ribhi aleyhâ", Dirâsâtü'l-meâyîri'ş-şer'yye 4 (1437/2015): 2747-2799, 3/2788.

17 Muhammed Abdulgaffar el-Şerif, "Ahkâmu tekvîni'l-muhassasât fi'l-müessesâti'l-mâliyyeti'lİslâmiyye", el-Mu'temeru'l-fikhî er-râbi' li'l-müessesâti'l-mâliyeti'l-İslâmiyye, (b.y.: y.y., 2011), 17, 20; Bayındır, "Faizsiz Bankacılıkta Kâr-Zarar Dağıtımı Uygulamasının Fıkhî Durumu”, 279.
} 
yatırmadıkları, bu durumun bir zaruret hâli olduğu ve bu nedenle böyle bir uygulamaya gidilmesinde herhangi bir beis görülmeyeceği ifade edilmiştir. ${ }^{18}$

Öte yandan zorunlu karşılık nemalarının gerçek anlamda faiz olduğu ileri sürülmüş buna göre zorunlu karşllık gelirlerinin reddedilmesi veya bu gelirlerin tamamını hayır işlerinde kullanılması istenmiştir. Çözüm olarak da Merkez Bankası'nın zorunlu karşılıklar için özel bir havuz oluşturması ve bu havuzda şerî yönetmelerle karşılıkları işletip kâr ödemesi yapabileceği teklif edilmiştir. ${ }^{19}$

Kamu otoritesinin zorunlu tutmuş olduğu karşılıkların nemaları geri ödendiğinde, sermaye sahiplerine verilirse kanaatimizce fıkhî açıdan bir sorun teşkil etmez. Çünkü hesap sahipleri, kendi sermayelerinin nemalarını almış olmaktadırlar. Yine katılma hesaplarından ayrılan ankes paylarının gelirleri de doğrudan hesap sahiplerine aktarılması gerekmektedir.

\section{B. Dağıtılacak Karlardan Ayrılan Rezervler}

Çağdaş literatürde dağıtılacak karlardan ayrılan rezervler, kâr dengeleme rezervi (احتياطي معدل الأرباح) şeklinde ifade edilir. Söz konusu rezerv, ülkemizde ilgili yönetmeliğin altıncı maddesinin (8) numaralı fıkrası çerçevesinde yürürlüğe girmiştir. ${ }^{20}$ Buna göre;

"Katılım bankaları, katılma hesapları için dönem sonlarında dağıtacakları kârlardan, müşteriyle imzalanacak sözleşmede hüküm yer alması, dokuzuncu ve onuncu fikralarda belirtilen maksatlar dışında başka amaçlarla kullanılmaması ve bakiyenin nihai olarak fon havuzuna aktarılması şartıyla kâr dengeleme rezervi ayırabilirler. Ayrılacak kâr dengeleme rezervine ilişkin azami oran ile uygulama usul ve esasları, Kurul tarafından belirlenir."

$\mathrm{Bu}$ rezervle hesap sahiplerinin yatırım gelirlerini belirli bir seviyede muhafaza etmek ve katılma hesabı kârını piyasa ile uyumlu hale getirme amaçlanmaktadır. ${ }^{21}$ Her iki tarafın maslahatına yönelik olduğu için de gayri safi kârdan karşılanması gerekmektedir. ${ }^{22}$ Ülkemizdeki uygulamada, kâr dengeleme

\footnotetext{
18 Hayrettin Karaman, "Munzam Karşıllk Faizi", Yeni Şafak (04 Eylül 2010) https://www.yenisafak.com/yazarlar/hayrettinkaraman/munzam-karilik-faizi-23870.

${ }^{19}$ Yunus Kutval, Türkiye Cumhuriyet Merkez Bankası Katılım Bankaları İlişkisi: Katıllm Finansmanı ve Zorunlu Karşıllk Kârı Modelleri (Konya: Necmettin Erbakan Üniversitesi Sosyal Bilimler Enstitüsü, Doktota Tezi, 2019), 109.

${ }^{20}$ Bankacılık Düzenleme ve Denetleme Kurumu, “Mevduat ve Katılım Fonunun Kabulüne, Çekilmesine ve Zamanaşımına Uğrayan Mevduat, Katılım Fonu, Emanet ve Alacaklara İlişkin Usul ve Esaslar Hakkında Yönetmelik".

${ }^{21}$ AAOIFI, Meâyîru'l-muhâsebe ve'l-müracaa ve'l-havkeme ve'l-ahlâkiyyât Menâme: Daru'l-meymân, 1437), 525.

${ }^{22}$ Abdulaziz Halife el-Kassar, "Ahkâmu tekvîni'l-muhassasât fi'l-bünûki'l-İslâmiyye eseruhâ a'lâ tevzîi'l-erbâh", el-Mu'temeru'l-fikhî er-râbi' li'l-müessesâti'l-mâliyeti'l-İslâmiyye (Kuveyt: Şeriketü Şu'râ, 2011), 40-67, 54.
} 
rezervi katılma hesabının gayrisafi kârından değil de yalnızca hesap sahiplerinin kârından ayrılmaktadır. Hesap sahipleri ile bankanın birlikte yararlanacağı bu rezervin, yalnızca hesap sahibinin gelirinden karşılanması, kârda ortaklık anlayışına zarar vermektedir. AAOIFI'nin standartlarında açıklandı̆̆ı gibi kâr dengeleme rezervinin katılma hesabının brüt kârından karşılanmasıyla bu durum düzeltilebilir. ${ }^{23}$ Böylece bankanın hem kendi kâr payından hem de özkaynağından feragat etmesine ihtiyaç kalmayacaktır.

\section{C. Özel ve Genel Karşılıklar}

Bankaların kullandırdı̆̆ı fonlar, dağıtılacak kârı olumlu ya da olumsuz olarak etkilemektedir. Bunun için bankalar, dağıtıma uygun kârlara ulaşmak amacıyla şüpheli alacaklar için karşılık ayırmaktadır. İlgili Yönetmelikte kullandırılan fonlar için ayrılan karşılıklar, beş ayrı grupta sınıflandırılmıştır. İlk iki grup genel karşılık, son üç grup ise özel karşılık olarak adlandırılmaktadır. Özel karşılık, mevcut durumda meydana gelmiş ama henüz tam olarak tespit edilememiş veya henüz gerçekleşmemiş zararlar için, genel karşılık ise gelecekte meydana gelmesi muhtemel olan zararlar için ayrılmaktadır. ${ }^{24}$

Günlük birim değer hesaplama tablosuna göre bu karşılıklar, uygulamada yalnızca hesap sahiplerinin kâr payından karşılanmaktadır. ${ }^{25}$ AAOIFI'nin faizsiz bankacılık standartlarına göre de bu karşılıkların katılma hesabının gayrisafi kârından alınması gerekmektedir. ${ }^{26}$ Kanaatimizce bu karşılıklar, mudârabe gideri olarak kabul edilmelidir. Zaten muhasebe tablolarında söz konusu karşılıklar "gider" kalemi olarak kaydedilmektedir. Bu durumda söz konusu karşılıkların gayri safi kârdan karşılanması zorunlu olmaktadır. Çünkü fıkha göre mudârabe sözleşmesinde gider, önce toplam kârdan karşılanmaktadır. ${ }^{27} \mathrm{Bu}$ durumda özel ve genel karşılıklar, sadece hesap sahiplerine dağıtılacak kârı değil de aynı zamanda bankanın payını da etkileyecektir. Katılım bankasını da aynı şekilde etkileyeceği için banka karşılık ayırırken daha dikkatli davranacaktır. ${ }^{28}$ Sonuçta hesap sahipleri ile banka kâr paylaşım oranlarına uygun olarak kârlarını alacaktır.

\footnotetext{
23 AAOIFI, Meâyîru'l-muhâsebe, 506.

24 Özgür Acar, "Bankalarca Ayrılan Karşılıklar: Teorik Yaklaşım ve Uluslararası Uygulamalar", Bankacilar Dergisi (2000), 34 (t.y.), 34.

${ }_{25}$ Ahmet Ocak, "Birim Değer-Hesap Değer Uygulaması ve Katılım Fonları: Sistemin İşleyişi”, Faizsiz Finans ve Tasarruf sistemleri ile İlgili Güncel Uygulamalar, (Ankara: Diyanet İşleri Başkanlığı Yayınları, 2019), 265-272, 269.

26 AAOIFI, el-Meâyîru'ş-şer'ıyye, 1015.

27 Osman b. Ali el-Zeylaî, Tebyinü'l-hakâik şerh-i kenzi'dekâik, (Çelebi haşiyesiyle), thk. Ahmed Azzu İnaye, (Beyrut: Dâru'l-kütübi'l-ilmiyye, 2010), 5/545; Alâüddîn Ebû Bekr b. Mes'ûd b. Ahmed el-Kâsânî, Bedâ'i'u's-sanâ' '̂́' fî tertîbi'ş-şerâ'i' (Beyrut: Dâru'l-kitâbi'l-ilmiyye, 1424), 8/68.

${ }^{28}$ Aydın Gündoğdu, Katılım Bankacılığında Kâr Dă̆ıtım Sisteminin Analizi ve Türkiye Uygulaması Için Yeni Bir Öneri (Müsvedde) (İstanbul: Sabahattin Zaim, 2020).
} 


\section{Masraflar}

Banka, katılma hesabı kaynaklı müşterilerine fon kullandırırken birtakım masraflar yapmaktadır. Bu masraflar, doğrudan ve dolaylı olmak üzere ikiye ayrılmaktadır. Banka, doğrudan yaptığı masrafları mudârabe sermayesinden, dolaylı yaptığı masrafları ise kendi özkaynağından karşılamaktadır. Çünkü dolaylı yaptığı harcamalar karşılı̆̆ında kârdan hisse almaktadır. ${ }^{29}$ Ancak mudârabe yatırımına yönelik doğrudan yapılan masraflar hususunda, mevcut faizsiz bankalar arasında henüz bir birlik oluşmamıştır. ${ }^{30}$ Ülkemizde ise kâr hesaplama tablolarında katılma hesabı masraflarından dahi bahsedilmemektedir. ${ }^{31}$ Günümüz bazı İslam İktisadı araştırmacıları çözüm olarak; katılma hesabı için ayrı bir departman kurulmasını ve bu departmanın bütün masraflarının da mudârabe sermayesinden karşılanmasını teklif etmektelerdir. ${ }^{32}$

\section{Sonuç}

Günlük birim değer hesaplama tablosunda, bütün işlemler hesap sahibinin kâr payı üzerinden yapılmaktadır. Oysa kâr paylaşımının adil bir şekilde yapılması için işlemlerin brüt kâr üzerinden yapılması gerekmektedir. Bunun için ilgili tablonun yeniden revize edilmesini zorunlu gözükmektedir. Aksi halde bankanın günlük kâr payını kendi hesabına aktarması durumunda bilahare meydana gelebilecek bir zarar, bankanın kâr payını etkilemeyecektir. Bu da mudârabenin gayesi olan kâr ortaklığına zarar verecektir.

Kâr hesaplama tablosundaki "Katılma Hesaplarına Dă̆ıtılacak Kârdan Ayrılan Tutarlar" başlıklı kalem, çağdaş literatürde kâr dengeleme rezervi olarak ifade edilmektedir. Söz konusu rezerv, uygulamada yalnızca hesap sahiplerinin kârından ayrılmaktadır. Halbuki hesap sahipleri ile bankanın birlikte yararlandığı bu rezervin, yalnızca hesap sahibinin gelirinden karşılanması, kârda ortaklık anlayışına zarar vermektedir. Kanaatimizce bu rezervin brüt kârdan karşılanması gerekmektedir. Ayrıca kâr dengeleme rezervi sebebiyle banka, diğer faizli bankaların faiz ödemeleri gibi sabit oranlı kâr dağıtımı yapabilmektedir. Bu da katılım bankalarının faizli bankalarla olan benzerliklerini daha da artırarak kamuoyunda olumsuz algıya yol açabilmektedir.

Diğer yandan AAOIFI standartlarında ayrıntılı olarak incelenen yatırım riskleri rezervi, katılım bankalarının kâr hesaplama tablosunda yer almamaktadır. Ancak sektör temsilcileri, bu rezervin kâr dengeleme rezervinin içinde olduğunu

\footnotetext{
29 AAOIFI el-Meâyîru'ş-şer'ıyye, 1014; Abdüssattar Ebu Gudde, “Karârâtü ve tevsîyâtü nedevâti'l-bereke li'l-iktisâdi'l-İslâmî", (2001), 61; Kassar, "Ahkâmu tekvîni'l-muhassasât", 51.

30 İsa, "el-Vedâiu'l-masrifiyye", 3/2780.

${ }^{31}$ Bankacllık Düzenleme ve Denetleme Kurumu, "Mevduat ve Katılım Fonunun Kabulüne, Çekilmesine ve Zamanaşımına Uğrayan Mevduat, Katılım Fonu, Emanet ve Alacaklara Illişkin Usul ve Esaslar Hakkında Yönetmelik".

32 Bayındır, “Faizsiz Bankacılıkta Kâr-Zarar Dağıtımı Uygulamasının Fıkhî Durumu”, 284.
} 
söylemektedir. Bu rezervin fıkha uygun olabilmesi için müstakil olarak ve yalnızca hesap sahiplerinin kârından ayrılması gerekmektedir.

Uygulamada, özel ve genel karşılık giderleri, yalnızca hesap sahiplerinin kârından karşılanmaktadır. Katılma hesabı taraflarının kârda ortak olmaları için giderlerin brüt kârdan karşılanması zorunludur. Çünkü mudârabede giderler toplam kârdan karşılanmaktadır. Aksi halde bu karşılıklar yalnızca hesap sahiplerinin kârını etkilemektedir. Karşılıklar, brüt kârdan karşılandığında bankanın kâr paylaşım oranı etkilenecek böylece banka karşılık ayırırken daha dikkatli davranacaktır.

Banka, doğrudan yaptığı masrafları mudârabe sermayesinden, dolaylı yaptığı masrafları ise kendi özkaynağından karşılamak zorundadır. Çünkü dolaylı yaptığı bu harcamalar karşılığında kârdan hisse almaktadır. Ancak günlük birim değer hesaplama tablosunda, katılma hesabı giderlerinden hiç söz edilmemektedir. Katılım bankalarının ana omurgasını oluşturan katılma hesaplarının gider kaleminin bu tabloda yer almaması, kanaatimizce faizsiz bankacılık anlayışına zarar vermektedir. 


\section{Kaynakça}

Acar, Özgür. "Bankalarca Ayrılan Karşılıklar: Teorik Yaklaşım ve Uluslararası Uygulamalar". Bankacilar Dergisi, 2000. 34 (t.y.).

Aktepe, Ishak Emin. Katıllm Finans. İstanbul: TKBB Yayınları, 2017.

Albarakatürk Katılım Bankacıllğı Sistemi Çalışma Esasları ve Uygulaması. b.y.: Albaraka Yayınları, ts.

AAOIFI. el-Meâyîru'ş-şer'tyye: en-nassu'l-kâmil li'l-mâyîri'ş-şeri'yye. Menâme: Daru'l-meymân, 2015.

AAOIFI. Meâyîru'l-muhâsebe ve'l-müracaa ve'l-havkeme ve'l-ahlâkiyyât. Menâme: Daru'l-meymân, 1437.

Bankacılık Düzenleme ve Denetleme Kurumu, BDDK. Kredilerin Sınıflandırılması ve Bunlar İçin Ayrılacak Karşılıklara İlişkin Usul ve Esaslar Hakkında Yönetmelik. Bankacılık Kanunu 5411: § Kredilerin Sınıflandırılması ve Yeniden Yapılandırılması (2017).

https://www.resmigazete.gov.tr/eskiler/2016/06/20160622-3.htm.

Bayındır, Servet. "Faizsiz Bankacılıkta Kâr-Zarar Dağıtımı Uygulamasının Fıkhî Durumu". Faizsiz Finans ve Tasarruf sistemleri ile İlgili Güncel Uygulamalar. ss. 100-115. Ankara 2019: Diyanet İşleri Başkanlığı Yayınları, 2017.

Ebecî, Kevser Abdulfettah Mahmut el-. "Kiyâsu ve tevzîu'r-ribh fi'l-benki'lİslâmî”. Mevsûaü'l-İktisâdi'l-İslâmî. Kahire: Dâru's-selâm, 2009.

Ebu Gudde, Abdüssattar. "Karârâtü ve tevsîyâtü nedevâti'l-bereke li'liktisâdi'l-İslâmî". 2001.

Gündoğdu, Aydın. Katılım Bankacılı̆̆ında Kâr Dağıtım Sisteminin Analizi ve Türkiye Uygulaması İçin Yeni Bir Öneri (Müsvedde). İstanbul Sabahattin Zaim, 2020.

İbnü'n-Neccâr, Fütûhî. Müntehe'l-irâdât fì cem'i'l-Mukni' ma'a't-Tenkîh ve ziyâdât. thk. Abdulmuhsin et-Türkî. Beyrut: Müessesetü'r-risâle, 1999.

İsa, Musa Adem. "el-Vedâiu'l-masrifiyye ve kavâidü tevzîi'r-ribhi aleyhâ". Dirâsâtü'l-meâyîri'ş-şer'yye 4 (2015 1437): 2747-2799.

İzmîrî, el-Allâme Muhammed Veli b. Resûl el-. Kemâlü'd-dirâye fî cemîi'r $r$ rivâye min şürûhi'l-Mültekâ. 11 Cilt. Beyrut: Dâru'l-kütübi'l-ilmiyye, 2017.

Kalkan, Cemal. Mudârabe Sözleşmesinde Kâr. İstanbul: İstanbul Üniversitesi Sosyal Bilimler Enstitüsü, Doktora Tezi, 2020.

Karaman, Hayrettin. "Munzam Karşılık Faizi”. Yeni Şafak. 04 Eylül 2010. https://www.yenisafak.com/yazarlar/hayrettinkaraman/munzam-karilik-faizi23870 . 
Kâsânî, Alâüddîn Ebû Bekr b. Mes'ûd b. Ahmed el-. Bedâ'i'u's-sanâ'î' fî tertîbi'ş-şerâ'i'. 2. Bs, 10 Cilt. Beyrut: Dâru'l-kitâbi'l-ilmiyye, 1424.

Kassar, Abdulaziz Halife el-. "Ahkâmu tekvîni'l-muhassasât fi'l-bünûki'lİslâmiyye eseruhâ a'lâ tevzîi'l-erbâh". el-Mu'temeru'l-fikhî er-râbi' li'l-müessesâti'lmâliyeti'l-İslâmiyye. 40-67. Kuveyt: Şeriketü Şu'râ, 2011.

Kutval, Yunus. Türkiye Cumhuriyet Merkez Bankası Katılım Bankaları İlişkisi: Katılım Finansmanı ve Zorunlu Karşılık Kârı Modelleri. Konya: Necmettin Erbakan Üniversitesi Sosyal Bilimler Enstitüsü, Doktora Tezi, 2019.

Makdisî (Kermî), Merî b. Yusuf. Gayetü'l-müntehâ fì cem'î'l-iknâ ve'l-müntehâ. nşr. Yasin İbrahim Mezrûî, Raid Yusuf Rûmî. Kuveyt, 2007.

Ocak, Ahmet. “Birim Değer-Hesap Değer Uygulaması ve Katılım Fonları: Sistemin İşleyişi”. Faizsiz Finans ve Tasarruf sistemleri ile İlgili Güncel Uygulamalar. Ankara: DİB Yayınları, 2019.

Osmânî, Muhammed Tâkî el-. Buhûsun fî kadâya fikhiyye muâsıra. 2 Cilt. Daru'l-kalem, 2011.

Serhî, Latif Muhammed Abdullah. Müşkilâtü ihtisâbi'l-erbâh ve tevzîihâ fi'lbunûki'l-İslâmiyye. Camiatü'l-Yermûk, 1995.

Şerif, Muhammed Abdulgaffar. "Ahkâmu tekvîni'l-muhassasât fi'lmüessesâti'l-mâliyyeti'l-İslâmiyye". el-Mu'temeru'l-fikhî er-râbi' li'l-müessesâti'lmâliyeti'l-İslâmiyye. Kuveyt Kervan Plaza, 2011.

Türkiye Cumhuriyeti Merkez Bankası, TCMB. “Mevduat ve Kredi Faiz Oranları ve Katılma Hesapları Kâr ve Zarara Katılma Oranları Hakkında Tebliği". $\begin{array}{llll}\text { Resmi } & \text { Gazete. } & 31 & \text { Mart }\end{array}$ https://www.resmigazete.gov.tr/eskiler/2020/02/20200210-9.htm.

Türkiye Katılım Bankaları Biriliği, TKBB. “Hesap Sahiplerine Dağıtılan Kar Payı Oranları". Organizasyon. 31 Mart 2020. https://www.tkbb.org.tr/kar-paylari.

Zeylaî, Osman b. Ali el-. Tebyinü'l-hakâik şerh-i kenzi'dekâik, (Çelebi haşiyesiyle). Thk. Ahmed Azzu İnaye. 7 Cilt. Beyrut: Dâru'l-kütübi'l-ilmiyye, 2010.

“Zorunlu Karşılıklar Hakkında Tebliğg”. Resmi Gazete. 25 Aralık 2013. 